\title{
Disabilities and Accessibility: Turkish Sample
}

\author{
Assoc. Prof. Hande Sahin \\ Karabuk University Faculty of Economics and Administrative Sciences Department of Social Work Karabuk/Turkey \\ Email: hande_k1979@yahoo.com \\ Master Student Burcu Savaş
}

Karabuk University Faculty of Economics and Administrative Sciences Department of Economics Karabuk/Turkey

\section{Doi:10.5901/ajis.2014.v3n3p238}

\section{Abstract}

Today, there are many handicapped people in the world, and their number is gradually increasing. According to a study conducted by World Bank and World Health Organization, today there are 1 billion handicapped people in the world. Handicapped people encounter countless obstacles everywhere both outside and in their own houses. These obstacles result in functional performance deficiencies and other problems for handicapped people, lower their quality of life qualities and cause various psychological and social problems. The problems of handicapped people should be considered to be an issue of global human rights; especially in Turkey, handicapped people experience many difficulties in their social lives. These problems might occur in many areas of life, and they prevent them from having a functionally integrated life in the society. The aim of this study is to identify the extent to which the legal, political, physical and social environment in Turkey allows persons with disabilities to participate in all realms of life equally with other individuals without being discriminated and; to evaluate state's obligations and make suggestions.

Keywords: disabilities, accessibility, Turkey

\section{Introduction}

People losing their physical, mental, sensory skills due to natural disasters, malnutrition, illnesses, accidents or since birth, therefore becoming disabled obstructs their living activities partially or fully and most importantly this complicates their social lives. In many places around the world, individuals have to live with mostly untreatable physiological deficiencies which prevent or obstruct them from using certain functions (Aytaç, 2005, p. 126, Beşer et. al., 2006, p. 267)

According WHO disabilities is an umbrella term, covering impairments, activity limitations, and participation restrictions. An impairment is a problem in body function or structure; an activity limitation is a difficulty encountered by an individual in executing a task or action; while a participation restriction is a problem experienced by an individual in involvement in life situations (WHO, 2011).

According to the definition of Turkish Statistical Institute (TurkStat), disabled person is the person, who lost their physical, mental, sensory and social abilities in some degrees due to whichever reason, who is unable to keep up with normal life requirements, who needs special physical reforms in structures and areas. (DIE, 2004)

In order to determine the requirements and demands of disabled individuals, types of disabilities are required to be known.

\section{Types of Disabilities}

It is not always possible to separate types of disabilities exactly. Some illnesses (cerebral palsy etc.) cause mental problems when untreated, sometimes even when treated and in some individuals it may cause orthopedic defects or both. Therefore, the cause of the disability is not important from the point of view of the disabled, function loss due to this factor or loss of work force is taken into consideration. (Çakmak, 2006)

People with disabilities are generally categorized as:

- Orthopedically handicapped

- Visually impaired

- Hearing impaired

- Language and speech handicapped 
- Mentally challenged

- Otherwise handicapped (DIE, 2004)

\subsection{Disabled Population in the World}

According to a study conducted by World Bank and World Health Organization, today there are 1 billion handicapped people in the world. A disability is any physical, sensory, or cognitive impairment that makes daily activities more difficult. Many people are born with a disability. Others acquire a disability later in life, from an accident, an illness, or the aging process. Many older individuals are diagnosed with chronic conditions that lead to functional or cognitive disabilities (World Health Organization (WHO), 2011)..

\subsection{Disabled Population in Turkey}

According to the disabled research of Turkish Statistical Institute (TurkStat) of 2002, the ratio of disabled population to total population is $12.29 \%$. It is determined that $1.25 \%$ of Turkish population is orthopedically handicapped, $0.60 \%$ are visually impaired, $0.48 \%$ are mentally challenged, $0.38 \%$ are language and speech handicapped, $0.37 \%$ are hearing impaired

\subsection{Accessibility}

Handicapped people encounter countless obstacles everywhere both outside and in their own houses (Müftüoğlu, 2006). These obstacles result in functional performance deficiencies and other problems for handicapped people, lower their quality of life qualities and cause various psychological and social problems (Ünügür, 2003). The problems of handicapped people should be considered to be an issue of global human rights; especially in Turkey, handicapped people experience many difficulties in their social lives. These problems might occur in many areas of life, and they prevent them from having a functionally integrated life in the society (Subaşıoglu, 2008). In order to solve this social issue, handicapped people should have access to and participate in social activities outside their homes (Müftüoğlu, 2006).

Designing and managing an accessible building means more than providing ramps and sufficient door widths these are important, but they must not become the focus of attention. There are many examples of projects with ramps and external doors that meet all the minimum requirements, yet they are totally inaccessible by a wide range of potential customers. There is a wide range of disabilities and they must all be taken into account when considering the design and management of a sports facility (EFDS, 2012). An accessible environment, while particularly relevant for people with disabilities, has benefits for a broader range of people. For example, curb cuts (ramps) assist parents pushing baby strollers. Information in plain language helps those with less education or speakers of a second language. Announcements of each stop on public transit may aid travellers unfamiliar with the route as well as those with visual impairments. Moreover, the benefits for many people can help generate widespread support for making changes (WHO, 2011).

"The Problems and Expectations of Disabled People" research conducted in 2010 revealed that that $66.9 \%$ of disabled people stated that sidewalks, walkways, pedestrian crossings, $66.3 \%$ stated that the buildings they live in, $59.5 \%$ stated that shops, and restaurants, $58.4 \%$ stated that public buildings, $55.4 \%$ stated that post offices and banks have not any reforms regarding disabled people. Generally, $68 \%$ of disabled people have no reforms in their vicinity, streets buildings and roads, regarding disabilities. Disabled people ratio who say the mass transportation services are suitable in their area is 4\%. Similar results are reached for health, education, employment. (TurkStat 2011). In the Research For the Discrimination Against Disabilities, most of the people who partake in the research (70.1\%) stated that public service buildings have no services or regulations for disabled people therefore they have difficulties, $44 \%$ face these difficulties most of the time or all the time. When accessibility is discussed in public areas such as roads, sidewalks and parks, ratios increase. $77.3 \%$ of the people who participated in the research stated that they have difficulties in transportation because there are no regulations regarding the disabled people. (OZIDA, 2010)

The physical environment the disabled people live in is very important because of the physical function deficiencies and the limitations caused by these deficiencies of the disabled people. When living areas are being designed, a society model is being presented, the physical environment that is going to be lived in is needed to be designed considering everybody who live in the society. (Karatas, 2014). 


\subsection{Regulations for the Disabled Population Accessibility in General Areas}

\section{Parking Areas}

Constructing parking areas just for the disabled population brings a lot of cost nowadays, while property prices are this high. In this situation, instead of constructing parking areas just for disabled population, it is more economical to reserve spaces for disabled population in general parking areas. (Mülayim and Özşahin, 2011). According to the Turkish Parking Area Regulation, in public building and area parking areas and general parking areas, it is mandatory to reserve no less than one parking space per 20 parking spaces with a disabled sign, in the closest proximity to entrance-exits of the parking areas and elevators. (Ministry of Public Works and Settlement, 1993).

\section{Sidewalks}

A pedestrian sidewalk for non-disabled people should be minimum 1.5 meters -ideally 2.0 - meters in width. Sidewalk width should be minimum 3.0 meters near bus stops, and 3.5 meters in front of shops. Sidewalk heights should be between 6 and $15 \mathrm{~cm}$. Ramps are required to be constructed in suitable places of the sidewalks for wheelchair accessibility. Slopes of the ramps should be taken approximately $8 \%$. If the widths of the ramps of the sidewalks are constructed as $140 \mathrm{~cm}$, two people walking side by side could access the ramp. (ÖZIDA, 2008).

In ÖZIDA (2008) publication, it is recommended that in order for the trees which grow on the sidewalks to be detected by visually impaired people, fences oppositely colored to the environment or pebbles should be placed to the bottom parts of the trees.

\section{Ramps}

Ramps are required to be constructed minimum $180 \mathrm{~cm}$ wide, as it will allow the passage of two wheelchairs moving in opposite direction. If the building main entrance is reached by stairs, maximum $6 \%$ sloped, minimum $1.20 \mathrm{~m}$ wide ramps with protective curbs and railings are required to be constructed. Ramps with more slope is difficult for disabled people usage. (OFD, 2004). For the visually impaired, a $150 \mathrm{~cm}$ long area with different texture should be present at the start and end of the ramps. (OZIDA 2008)

\section{Stairs}

As stairs obstruct the movement of the disabled people, it is important from the point of accessibility that different elevations are joined by ramps. If the stairs are unavoidable, guardrails should be put to both sides. In order for the visually impaired to detect and the stairs, surfaces that respond to senses should be used. Surface that respond to senses should start just before the first step, and end at the end of stairs after one width of a step. (OZIDA 2010)

\section{Elevators}

Elevators cause different problems for the people with different types of disabilities. Width of the elevator cabin must be minimum $110 \mathrm{~cm}$, depth must be minimum 140cm (OFD, 2004). Lifts are divided into three groups from 1000mm width and $1250 \mathrm{~mm}$ depth (capacity for 1 wheelchair user) to $2000 \mathrm{~mm}$ width and 1400 $\mathrm{mm}$ depth (capacity for 1 wheelchair user and a few other passengers). These are the minimum measurements and in some elevators with these measurements, large wheelchairs may be unable to enter or passengers may be unable to sit with their legs stretched out. Therefore if area is sufficient, minimum depth should be $1400 \mathrm{~mm}$ (preferably $1500-1800 \mathrm{~mm}$ ) and minimum width should be $14000 \mathrm{~mm}$ (preferably $2000 \mathrm{~mm}$ ) as shown in diagram. European standards also state that doors should be $900 \mathrm{~mm}$ wide and interior height should be $2300 \mathrm{~mm}$. Door height should be $2100 \mathrm{~mm}$. In elevators with double doors, $900 \mathrm{~mm}$ door width is sufficient. In elevators with single doors, this width should be $1100 \mathrm{~mm}$. Interior height of the elevator should be $2100 \mathrm{~mm}$ at the entrance and $2300 \mathrm{~mm}$ inside. In order to help the visually impaired, buttons should be embossed in regular text and Braille. Visual informing for all users regarding their commands are accepted should be used. Besides pre-recorded announcements, stating the floor and direction of movement should be used (OZIDA, 2008) 


\section{Restaurants and Cafes}

Enough restaurants, cafes, cafeterias should provide suitable facilities for the disabled people. Some of the tables at restaurants should be prepared for customers in wheelchair. For this, tables with no fixed chairs and tables with sufficient ground clearance and space underneath should be used for disabled guests. Moreover, in restaurants, for visually impaired, menus with large and bold fonts should be present (Artar and Karabacakoğlu 2003).

\section{Assembly Halls and Entertainment Venues}

Area reserved for one wheelchair should be no less than $900 \times 1400 \mathrm{~mm}$. It is preferred that these areas are distributed throughout the assembly halls (TMMOB, 2012).

\section{Pedestrian Zones}

As a general principle, station utilities should be designed in a way that they should not obstruct pedestrian flow and they should take up small spaces. Utilities such as phones, vending machines, banks, garbage boxes should be placed so that they can be easily seen and used, but in a way that they do not obstruct pedestrian corridors. A pedestrian road with a width of minimum $2000 \mathrm{~mm}$ where there are no obstacles should be present. This road should incorporate pavements which respond to senses for the visually impaired, and columns supporting the roof and station utilities should be oppositely colored to their environments. If there are columns in the main way of pedestrians, these should be marked with two stripes, 140 or $160 \mathrm{~mm}$ wide, green and black striped, bottom side is $800 \mathrm{~mm}$ high and top side is $1600 \mathrm{~mm}$ high (OZIDA, 2008)

\section{Pool, Sauna, Bathhouse}

In places like pools, saunas and bathhouses, accessibility inside the venue is as much important as transportation to the venue. Especially in saunas and bathhouses, unnecessary elevations over the floor should be avoided. Empty space for the wheelchair to maneuver should be provided. As pools are larger structures, maneuver problems occur less than saunas and bathhouses. The biggest problem in pools occurs when users try to go into or get out of the pool. The easiest solution to this problem is to build elevators that have rotary, vertical and horizontal motions inside the pool (Mülayim and Özşahin, 2011, p 1676)

\section{Main Entrances}

Most buildings have unsuitable entrances for the disabled people. If it is unavoidable to have stairs in entrances, guardrails must be present. Different elevations should be joined by ramps. Ramp slopes should not be higher than five degrees, they should have railings and passage width should be at least $100 \mathrm{~cm}$ (Yörük, 2003)

\section{General Restrooms}

For restrooms for the disabled people, it is very beneficial that they have railings on the walls on their sides and their back (Yörük, 2003). Door width for the restrooms should be minimum $81.5 \mathrm{~cm}$, they should open outwards. In order to provide comfortable movement, toilet axis and the wall on the side should have $45 \mathrm{~cm}$ space between them. Besides enough free space should be provided in front of and beside the toilet seat for the wheelchair users to come close and sit safely.

As with all people, disabled people should be able to benefit from all services equally and they should be able to travel to work, school, shopping, sports areas, parks using the same roads and vehicles as non-disabled people. Local administrations have an important role in the shaping of the city with their social and technical investments. The fact that public transportation services and accessibility of every open area and building in the city are provided by local administrations is the most important factor that enables the disabled people to join the social life with equal opportunities (Ozturk, 2011). 


\section{References}

Artar, Y. ve Karabacakoğlu, Ç. (2003). Türkiye'de Özürlüler Turizminin Geliştirilmesine Yönelik Olarak Konaklama Tesislerindeki Alt Yapı Olanaklarının Araştırılması. Ankara: Milli Prodüktivite Merkezi.

Aytaç, S. (2005). İstihdam ve Koruma Alanı Yaratmak Üzere Özürlüler İçin Sosyal Yaşam. Sosyal Siyaset Konferansları 49. Kitap, İstanbul.

Bayındırlık ve İskan Bakanlığı (1993). Otopark Yönetmeliği. Erişim: 12.03.2009 [http://www.mevzuat.adalet. gov .tr/html/20365.html]

Beşer, E., Atasoylu, G., Akgör, Ş, Ergin, F. ve Çullu, E. (2006). Aydın İl Merkezinde Özürlülük Prevelansı, Etiyolojisi ve Sosyal Boyutu. TSK Koruyucu Hekimlik Bülteni 5(4); 267-275

Çakmak, N.M. (2006). Türk Kamu Hukuku Açısından Engellilerin Hukuki Statüsü. Doktora tezi, Ankara Üniversitesi, Ankara.

Devlet İstatistik Enstitüsü (DIE) (2004). Türkiye Özürlüler Araştırması 2002. Devlet İstatistik Enstitüsü Matbaası, Ankara.

English Federation of Disability Sport (EFDS) (2013). Access for disabled people. http://www.rfu.com/managingrugby/clubdevelopment /facilitiesandequipment/ /media/files/2009/facilitiesandequipment/disabled.ashx

Karatas, K. (2014). Engellilerin toplumla bütünleşme sorunları. http://www.sosyalhizmetuzmani.org/engellitoplum.htm

Müftüoğlu, U. (2006). Tekerlekli Sandalye Kullanan Bedensel Engellilerin Kentsel Mekanları Kullanım Olanaklarının Trabzon Kent Merkezi Örneği Üzerinde İncelenmesi. Yüksek lisans tezi, Karadeniz Teknik Üniversitesi, Trabzon.

Mülayim, A. ve Özşahin, B. (2011). Bedensel Engellilerin Konaklama Sorunları ve Çözüm Önerileri Üzerine Bir İnceleme. Öz-Veri Dergisi 7 (2); 1663-1684.

Omurilik Felçlileri Derneği (OFD) (2004). Özürlü Kişilere Uyarlanmış Yapı: SN 521500 Normlarıyla Ulaşılabilirlik Klavuzu, İstanbul.

OZIDA (Başbakanlık Özürlüler İdaresi Başkanlığı) (2008). Herkes İçin Ulaşılabilirliğin İyileştirilmesi: Örnek Uygulama Rehberi, assından çeviri, Başbakanlık Özürlüler İdaresi Başkanlığı, yayın no: 48, Ankara.

OZıDA (2010). Özürlülüğe Dayalı Ayrımcılığın Ölçülmesi Araştırması. s.123 http://www.ozida.gov.tr/ayrimciliklamucadele/rapor_tum.pdf (10.06.2011)

OZIDA (2010). Yerel yönetimler için ulaşılabilirlik temel bilgiler teknik el kitabı. Editörler: Kaplan, H., Yüksel, Ü., Gültekin, A.B, Güngör, C., Karasu, N., Çavuş, M. Ankara

TMMOB (2012). Ulaşılabilirlik klavuzu. http://www.mimarist.org/2012-06-08-21-56-28/ulasilabilirlik-kilavuzu.html

Ozturk, M. (2011). Türkiye'de engelli gerçeği. MUSIAD Cep Kitapları: 30, İstanbul.

Subaşıoğlu, F. (2008). Üniversitelerin Bilgi ve Belge Yönetimi Bölümleri'nin "Engellilik Farkındalığı" Üzerine Bir Araştırma. Bilgi Dünyası 9(2); 399-430.

TSE (1991). TS 9111 Özürlü İnsanların İkamet Edeceği Binaların Düzenlenmesi. Ankara: Türk Standartları Enstitüsü Matbaası.

TUIK (2011). Özürlülerin Sorun ve Beklentileri Araştırması, TÜIK Haber Bülteni, Sayı:71,

7 Nisan http://www.tuik.gov.tr/OncekiHBZip.do?komut=preArama (13.06.2011).

Ünügür, M. (2003). Özürlülerin Ergonomik Boyutları. Mimarist Dergisi 2003/2;99102.

Yörük, Ü. K. (2003); Turizm Yapılarının Tasarımında Özürlü Etmeninin İrdelenmesi. Yüksek lisans tezi, Yıldız Teknik Üniversitesi, İstanbul.

World Health Organisation (WHO) (2011). World report on disability http://www.who.int/disabilities/world_report/2011/report/en/ 